\title{
Medizynischer Liebeskummer
}

Ich hab' meine Liebe aufs Eis gelegt Meine Sehnsucht bleibt tiefgekühlt Ich hab' auch gar keinen Groll gehegt Als sie sich in sein Bett gelegt Ich hab' nur die Leere gefühlt.

Meine Liebe, das war doch bloss «Projektion» Eines «angeborenen Schemas» Infolge gesteigerter Funktion Der Drüsen mit «innerer Sekretion» Im Sinn jenes uralten Themas

Das uns Natura ins Herz geschrieben In Form einer "Servomechanik» Zur Arterhaltung soll man sich lieben Und zeugend die sämtlichen Gene verschieben Weshalb dann im Mai diese Panik
Sobald nun ein Mann so ein Weibchen erblickt Mit allen «Signalen des Sexus»

Wird jeglicher Zweifel im Keime erstickt Und im Weibchen das Ziel aller Träume erblickt. Der Rest ist ein reiner «Reflexus.»

Nun nehm' ich zurück, was ich selbst projiziert Das Idol mit vollkommenen Formen

Und von dem, was da bleibt, wird noch mehr reseziert Und das treulose Faktum wird wegsuggeriert Und es bleiben alltägliche Normen.

Und die Liebe, sie ist doch ein leerer Wahn Schon Ovid sagt: amantes - amentes! Der Verliebte ist stets ein «betrogener Hahn» Die Geliebte folgt nie seiner Sehnsüchte Bahn Und das Ende vom Liede - man kennt es!

Hans Martin Sutermeister, Bern (Jahr unbekannt)

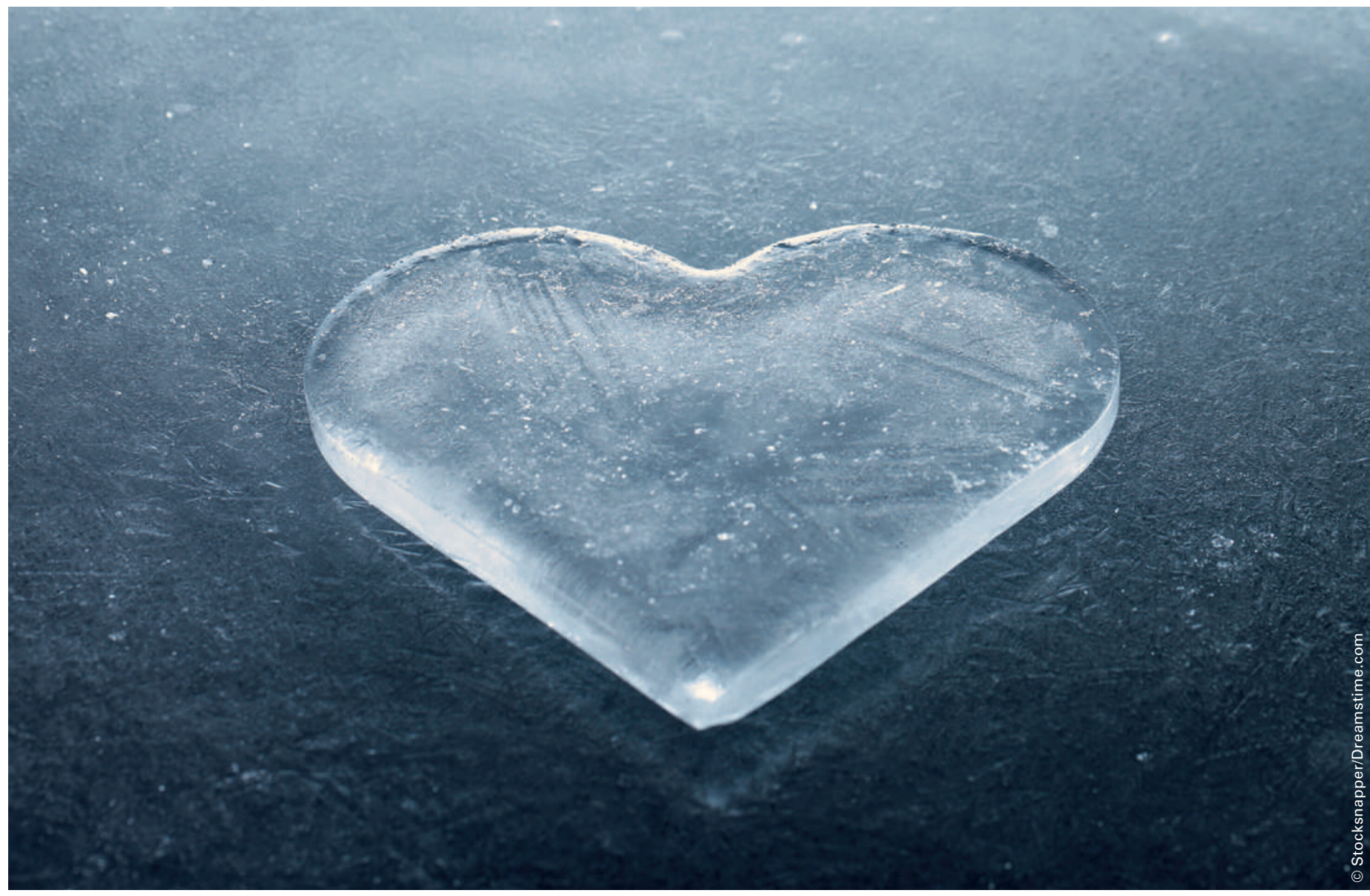

